\title{
What would make your life better? A needs analysis of leprosy settlements in the middle belt region of Nigeria
}

\author{
OSAHON OGBEIWI* \& JUNE NASH** \\ *The Leprosy Mission International, Nigeria Co-ordination Office, \\ 1, Ladi Kwali Road, P.M.B. 179 Minna, Niger State, Nigeria \\ **The Leprosy Mission International, 80 Windmill Road, Brentford, \\ Middlesex TW8 OQH, United Kingdom
}

Accepted for publication 30 June 1999

\begin{abstract}
Summary A needs analysis using rural appraisal and matrix ranking techniques was done in six leprosy communities in the middle belt region of Nigeria. Asked 'what would make their life better?' whole village groups were made to list, prioritize and rank their expressed needs by voting in a matrix table drawn on the ground. Out of a total of 504 votes, $31 \%$ was for health care or drugs for their general ailments, $23.6 \%$ for money and less than $10 \%$ for other needs that ranged from water, trade and housing to love and, least, mobility aids. Health care was prioritized in all communities but got the highest votes in three communities, money got the highest in the only two communities where it was prioritized and water in one. The need ranked the highest in each settlement seemed to be a reflection of its peculiar socio-economic situation. Apart from the similar priorities of health care and money, men's differing priorities were water, housing, clothes and assistance with farming, and women's, school fees for children, family, trade and food. These reflect their different traditional roles. Considering the variety of needs we think that there is no one solution to rehabilitation in the Nigerian context, but the situation and context of individual settlements should be considered, looking at general health care, income generation or loans schemes, schooling and water supply.
\end{abstract}

\section{Introduction}

Leprosy settlements in Nigeria are the results of cured leprosy patients being unable to return home due to external or self-stigma. The settlements are associated with old leprosaria, some of which are now closed. During the dapsone era, many patients were kept in hospital compounds so that they could receive regular treatment. Over the years some of the settlements developed into villages, with people affected by leprosy settling 
there and farming. Some people have lived in them for over 40 years. With the present focus of most national leprosy control programmes being elimination of leprosy, little attention, if any, is being paid to the plight of these ex-patients living in leprosy communities. The Leprosy Mission International (TLMI) has prioritized development of leprosy communities through partnership with persons affected by leprosy. ${ }^{1}$ It was decided that a needs assessment should be done to investigate the help needed by the leprosy settlements in assisted programmes in Nigeria. The analysis was done without committing TLMI to anything and bearing in mind the policy of the Nigerian government to close leprosy settlements and resettle persons affected by leprosy in their own home communities.

The aim of the needs analysis was to gain an overview of the situation in leprosy communities in order to develop a sustainable rehabilitation programme. The programme should seek both to meet the needs and where possible, encourage re-integration. This paper summarizes the situation of leprosy communities in three States, Niger, Kogi and Kwara States, describes the role of leprosy hospitals more from the viewpoint of settlers, and lists and ranks the expressed needs in settlements. Also investigated were their opinions about returning home and what they would need to achieve this.

\section{Materials and methods}

The needs analysis used qualitative and rural appraisal methods to investigate, list and rank the expressed needs of people affected by leprosy living in seven leprosy communities in three contiguous States in the middle belt region of Nigeria. The situation of the leprosy communities was reviewed using existing quantitative data, direct observation and comments from the villagers. Semi-structured group interviews were used to find out the villagers' view of the role of the existing leprosy hospitals adjoining the settlements.

In each settlement, villagers were gathered into one big group of 12-47 people with men and women seated separately. After our own introduction, they were asked to introduce themselves and say how long they had been in the settlement. The main research question 'What would make your life better?' was then asked. The question was asked to individuals and then four or five priorities were given from the larger list. Men were asked to give three and women two. These five were then put into a matrix table drawn on the ground with articles from around the village representing the choices given. For example, if water was a choice, then a bowl of water was put into the square. If health care, then some drugs were in the square. The villagers were then given two sticks to vote with. Men and women were asked to vote separately.

Initially, the matrix had two columns, one for improving their family life and the second for improving their status. This was an attempt to look at stigma. However, the second column was not used, so we used a ranking matrix with first and second choice. At the end of the matrix ranking, the villagers were asked whether they could go home, and then what they would need to do to be able to return home. The final question asked about the settlers' views on the role of the adjoining leprosy hospital. After the group session, some quantitative data was collected using a structured checklist regarding the social and economic situation of the settlements. Interpreters were used to ask the questions and the translated answers were recorded. A diary of each visit was made, noting observations about the village structure and the people affected by leprosy. 


\section{Results}

The needs analysis was done in August 1997 in six leprosy communities. These include Kuta and Tunga-Minna in Niger State, Ochadamu and Oyi-River in Kogi State, and Okegbala and Elehin in Kwara State. Three communities, each with a leprosy hospital, had more than one settlement-Chanchaga (2), Ochadamu (2) and Okegbala (3). Two communities, Kuta and Oyi-River, were beside now-closed leprosy institutions. Tunga-Minna is an urban community with people affected by leprosy living in a section of a city. Three communities including Tunga-Minna, Kuta and Elehin were now recognized as bone-fide integrated communities with people affected by leprosy and non-leprosy affected people living side by side.

\section{SITUATION OF THE LEPROSY COMMUNITIES}

Apart from Elchin and Tunga-Minna, the five communities were situated within a range of $1-15 \mathrm{~km}$ from the nearest town. The number of houses in each settlement ranged from 5 to 47 and all six communities had a population of 624 people, with an average of five persons affected by leprosy living in each house. Each house had up to two to four rooms or huts. The settlements that had grown out of leprosaria had houses built by the settlers themselves, made of local materials, and matched those of the surrounding non-leprosy villages. The buildings in the hospital-based settlements were built by the hospital and were dormitory-like with males and females living separately. In virtually all communities, the population has been decreasing in the last 10 years. Subsistence farming was the main occupation, but the land belonged either to the hospital or the local government. Begging was another major occupation in two communities, Tunga-Minna (urban) and Okegbala. Most appeared to have a good variety of crops, though the distance to their farms was variable and some had to walk long distances to their fields. In two groups, there were business activities: palm oil and petty trading.

Each settlement had a chief or leader, of ten one of the older, more disabled men. Most of the people affected by leprosy had been in the settlement for more than 20 years. The shortest time spent was 2 years and the highest more than 50 years. Some had gone home and returned. There was a mix of people in all settlements, though the majority seemed to be middle-aged or above and visibly disabled. The disability status for the various age groups was not assessed. Wells and streams were the most common source of water. In some, the streams were far and seasonal and the wells could be very deep. Only the urban communities in Minna had a borehole or tap. Source of light was mainly the bush lamp. One had a generator and the urban community enjoyed the electricity supply in the city. In four out of the six communities, settlers had to walk the $1-15 \mathrm{~km}$ to the nearest town to shop or grind their produce. Apart from those living close to leprosy hospitals, there was no easy access to a health facility.

PRIORITY RANKING OF NEEDS

A total of 252 people, 115 men and 137 women, voted in the matrix priority ranking of their needs in all six communities. The matrix table in Table 1 shows the ranking of the list of all priorities given. It shows that the majority of the villagers (31\% of 504 votes cast) needed health care. Health care was followed by money with $23.6 \%$, but unlike health care, which was prioritized in all settlements, money was prioritized in only two communities. The 
Table 1. Matrix table showing the priority ranking of needs in six leprosy communities in the middle-belt region of Nigeria

\begin{tabular}{lrrrrrrrr}
\hline List of priorities & Kuta & Ochadamu & Oyi-River & Okegbala & Elehin & Tunga & Total & Ranking \\
\hline Health care & 12 & 2 & 35 & 63 & 10 & 34 & 156 & 1 \\
Money & $\mathrm{X}$ & 13 & $\mathrm{X}$ & 106 & $\mathrm{X}$ & $\mathrm{X}$ & 119 & 2 \\
Water & 18 & $\mathrm{X}$ & 24 & 1 & $\mathrm{X}$ & $\mathrm{X}$ & 43 & 3 \\
Trade & $\mathrm{X}$ & $\mathrm{X}$ & $\mathrm{X}$ & 14 & 9 & 18 & 41 & 4 \\
House & $\mathrm{X}$ & $\mathrm{X}$ & $\mathrm{X}$ & 37 & $\mathrm{X}$ & $\mathrm{X}$ & 37 & 5 \\
School fees & $\mathrm{X}$ & $\mathrm{X}$ & 22 & 12 & $\mathrm{X}$ & 2 & 36 & 6 \\
Food & $\mathrm{X}$ & 5 & $\mathrm{X}$ & $\mathrm{X}$ & 3 & 19 & 29 & 7 \\
Grinding mill & $\mathrm{X}$ & $\mathrm{X}$ & 9 & $\mathrm{X}$ & $\mathrm{X}$ & $\mathrm{X}$ & 9 & 8 \\
Light & $\mathrm{X}$ & $\mathrm{X}$ & $\mathrm{X}$ & 7 & $\mathrm{X}$ & $\mathrm{X}$ & 7 & 9 \\
Handwork & $\mathrm{X}$ & 1 & 4 & $\mathrm{X}$ & $\mathrm{X}$ & $\mathrm{X}$ & 5 & 10 \\
Clinic repairs & 5 & $\mathrm{X}$ & $\mathrm{X}$ & $\mathrm{X}$ & $\mathrm{X}$ & $\mathrm{X}$ & 5 & 10 \\
Clothes & $\mathrm{X}$ & 4 & $\mathrm{X}$ & $\mathrm{X}$ & $\mathrm{X}$ & $\mathrm{X}$ & 4 & 11 \\
Footwear & $\mathrm{X}$ & 1 & $\mathrm{X}$ & $\mathrm{X}$ & $\mathrm{X}$ & 3 & 4 & 11 \\
Fertilizer & 3 & $\mathrm{X}$ & $\mathrm{X}$ & $\mathrm{X}$ & $\mathrm{X}$ & $\mathrm{X}$ & 3 \\
Family/love & $\mathrm{X}$ & 3 & $\mathrm{X}$ & $\mathrm{X}$ & $\mathrm{X}$ & $\mathrm{X}$ & 3 & 12 \\
Assist farming & $\mathrm{X}$ & $\mathrm{X}$ & $\mathrm{X}$ & $\mathrm{X}$ & 2 & $\mathrm{X}$ & 2 \\
Mobility & $\mathrm{X}$ & 1 & $\mathrm{X}$ & $\mathrm{X}$ & $\mathrm{X}$ & $\mathrm{X}$ & 1 & 12 \\
Total & 40 & 30 & 94 & 240 & 24 & 76 & 504 & 14 \\
& & & & & & & &
\end{tabular}

priorities that received less than $10 \%$ but more than $1 \%$ of votes each were, in descending order, water, trade, housing, school fees, food, grinding mill, and electricity. Other priorities with less than $1 \%$ of votes each were handwork, clinic repairs, clothes, footwear, fertilizer, family, assistance with farming and, lastly, mobility aids. Table 2 shows the highest priorities of the individual communities, and revealed health care as the highest priority and first choice in three out of the six communities and as second choice in two. Money was the highest first choice in the two communities where it was mentioned. Trade was a highest first choice in one community only and water, a highest priority as a second choice in two communities. Clothes and food were the other highest priorities as second choice in another two communities.

Table 2. The highest-ranking priorities of the individual leprosy communities in the middle belt region of Nigeria

\begin{tabular}{lllc}
\hline Community & \multicolumn{1}{c}{$1^{\text {st }}$ choice } & $2^{\text {nd }}$ choice & No. of voters \\
\hline Kuta & Health care $(55 \%)$ & Water $(65 \%)$ & 20 \\
Ochadamu & Money $(67 \%)$ & Food $(27 \%)$ & 15 \\
& & Clothes $(27 \%)$ & 47 \\
Oyi-River & Health care (55\%) & Water (36\%) & 120 \\
Okegbala & Money $(68 \%)$ & Health care $(43 \%)$ & 12 \\
Elehin & Trade $(50 \%)$ & Health care $(50 \%)$ & 38 \\
Tunga & Health care $(66 \%)$ & Food $(39 \%)$ & 252 \\
Total & & & \\
\hline
\end{tabular}


Table 3. Priority ranking of needs by men and women in leprosy communities in the middle-belt of Nigeria

\begin{tabular}{|c|c|c|c|c|c|c|}
\hline \multirow[b]{2}{*}{ List of priorities } & \multicolumn{3}{|c|}{ Men $n=115$} & \multicolumn{3}{|c|}{ Females $n=137$} \\
\hline & Votes & $\%$ & Ranking & Votes & $\%$ & Ranking \\
\hline Health care & 73 & $32 \%$ & 1 & 83 & $30 \%$ & 1 \\
\hline Money & 50 & $22 \%$ & 2 & 69 & $25 \%$ & 2 \\
\hline Water & 26 & $11 \%$ & 3 & 17 & $6 \%$ & 5 \\
\hline Trade & 17 & $7 \%$ & 5 & 24 & $9 \%$ & 4 \\
\hline House & 21 & $9 \%$ & 4 & 16 & $6 \%$ & 6 \\
\hline School fees & 11 & $5 \%$ & 6 & 25 & $9 \%$ & 3 \\
\hline Food & 13 & $6 \%$ & 5 & 16 & $6 \%$ & 6 \\
\hline Grinding mill & 2 & $0.9 \%$ & 9 & 7 & $3 \%$ & 7 \\
\hline Light & 0 & $0 \%$ & 11 & 7 & $3 \%$ & 7 \\
\hline Handwork & 4 & $2 \%$ & 7 & 1 & $0.4 \%$ & 9 \\
\hline Clinic repairs & 2 & $0.9 \%$ & 9 & 3 & $1 \%$ & 8 \\
\hline Clothes & 4 & $2 \%$ & 7 & $\mathrm{X}$ & $\mathrm{X}$ & $X$ \\
\hline Footwear & 1 & $0.4 \%$ & 10 & 3 & $1 \%$ & 8 \\
\hline Fertilizer & 3 & $1 \%$ & 8 & 0 & $0 \%$ & 10 \\
\hline Family/love & $\mathrm{X}$ & $\mathrm{X}$ & $X$ & 3 & $1 \%$ & 8 \\
\hline Assist farming & 2 & $0.9 \%$ & 9 & 0 & $0 \%$ & 10 \\
\hline Mobility & 1 & $0.4 \%$ & 10 & $\mathrm{X}$ & $\mathrm{X}$ & $\mathrm{X}$ \\
\hline Total & 230 & $100 \%$ & & 274 & $100 \%$ & \\
\hline
\end{tabular}

Table 3 compares the choices of all the men and women. The first and second ranked priorities of men and women were the same-first, health care and second, money. The order of the other priorities is different for the two sexes. For instance, the third, fourth and fifth priorities for men were water, housing and trade, while for women these were school fees for children's education, trade and water. In Figure 1, it is seen that more men than women

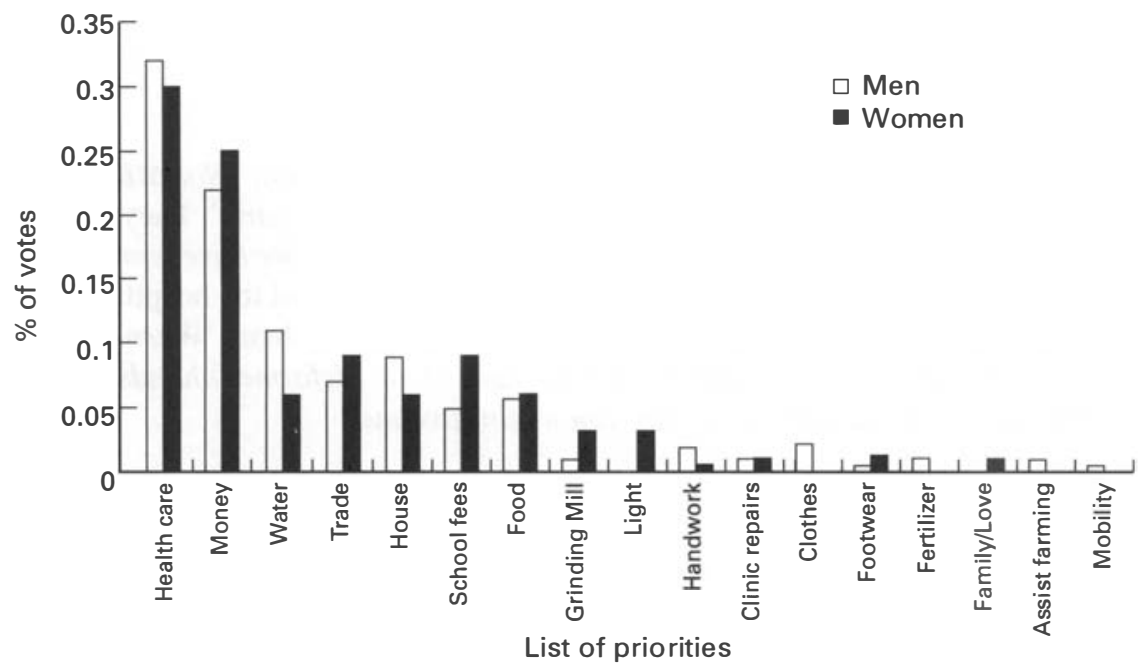

Figure 1. Comparison of choice of priority needs by men and women in leprosy communities in the middle-belt region of Nigeria. 
Table 4. Highest-ranking priorities of men and women in the leprosy communities in the middle-belt region of Nigeria

\begin{tabular}{|c|c|c|c|c|c|c|}
\hline \multirow[b]{2}{*}{ Community } & \multicolumn{3}{|c|}{ Men } & \multicolumn{3}{|c|}{ Women } \\
\hline & $1^{\text {st }}$ choice & $2^{\text {nd }}$ choice & $n$ & $1^{\text {st }}$ choice & $2^{\text {nd }}$ choice & $n$ \\
\hline Kuta & $\begin{array}{l}\text { Health care } \\
\quad(55 \%)\end{array}$ & Water (55\%) & 11 & $\begin{array}{l}\text { Health care } \\
\quad(56 \%)\end{array}$ & Water (78\%) & 9 \\
\hline Ochadamu & Money (71\%) & Clothes (57\%) & 7 & Money (63\%) & Food (38\%) & 8 \\
\hline Oyi-River & $\begin{array}{l}\text { Health care } \\
\quad(68 \%)\end{array}$ & Water (50\%) & 28 & $\begin{array}{l}\text { School fees } \\
\quad(42 \%)\end{array}$ & $\begin{array}{c}\text { Grinding mill } \\
(37 \%)\end{array}$ & 19 \\
\hline Okegbala & Money (73\%) & $\begin{array}{l}\text { Health care } \\
\quad(42 \%)\end{array}$ & 45 & Money (65\%) & $\begin{array}{c}\text { Health care } \\
(43 \%)\end{array}$ & 75 \\
\hline Elehin & Trade $(50 \%)$ & $\begin{array}{l}\text { Health care } \\
\quad(50 \%)\end{array}$ & 6 & $\begin{array}{l}\text { Health care } \\
\quad(50 \%) \\
\text { Trade }(50 \%)\end{array}$ & $\begin{array}{l}\text { Health care } \\
\quad(50 \%)\end{array}$ & 6 \\
\hline Tunga-Minna & $\begin{array}{c}\text { Health care } \\
\quad(50 \%)\end{array}$ & $\begin{array}{l}\text { Health care } \\
(33 \%) \\
\text { Food }(33 \%) \\
\text { Trade }(33 \%)\end{array}$ & 18 & $\begin{array}{l}\text { Health care } \\
(80 \%)\end{array}$ & Food $(45 \%)$ & 20 \\
\hline Total & & & 115 & & & 137 \\
\hline
\end{tabular}

$n=$ Number of voters.

wanted health care, water, house, and handwork. More women wanted money, trade, school fees, grinding mill and footwear. Only men wanted clothes, fertilizer for their farms, assistance with farming and means of mobility whilst only women wanted light (electricity) and family or love. Table 4 shows that the highest-ranking first and second choices of both men and women were the same in all but two communities. In those two communities, men wanted clothes and water while women wanted food and grinding mills.

\section{REASONS FOR THE FIRST CHOICES}

\section{Health care}

When asked what they meant by health care, the villagers replied, 'Not MDT (multi-drug therapy) but drugs for other diseases: we need general health care.' They said this was largely because of stigma. 'If we go to ordinary clinics they tell us we have leprosy and do not attend to us!' Those close to the leprosy hospitals said they wanted the hospitals to be better equipped to provide them with general health services. For one of them, 'When I am healthy, I can do many other things. Now I cannot farm because of my (deformed) hands.' For another, 'When I am healthy, I can use the money you might give me.'

\section{Money}

It was found that money was the top priority in the settlements that were not so functional as villages - those still dependent on their attached hospitals or where begging was a main occupation. When the settlers were asked why they had made money their first choice, a variety of answers was given to identify exactly what they meant by money. Some were asking for loans to develop income generation and others wanted more of a regular pension. 
The older ones and the more disabled who could not trade wanted money for food. When asked whether they wanted money or an occupation, the persons affected by leprosy replied, 'We have no hands and feet, how can we work?' Some groups felt that money would solve all their problems since it could be used in so many ways: 'We can use it to buy anything we want. Any one who has money can use it for anything. If I have money, I will buy food, also to build my house, in fact, everything I want!' Linking money with rehabilitation, one woman said, 'The machine for sewing that I want to buy can be bought with money,' and a man, 'Money will buy tools for my children.'

\section{Others}

Water was a high priority second choice in two settlements. One was an isolated village where a deep and almost dry well was the only source of water. The other community gets water from a distant stream. Clothes and love were priorities in a particular community where male and females live in two separate dormitories. Food as a specific need was a high priority in communities with more of the very old and disabled persons who could neither farm nor walk to beg. This was the case especially in the urban community.

\section{FACTORS THAT PREVENT RESETTLEMENT AT HOME}

All settlers were informed of the government return home policy. There were many reasons why they felt they could not return home. These included the leprosy stigma and disabilities, family problems, care at home, employment and no housing.

\section{Stigma and disabilities}

Many believed that because of their disabilities, they would not be received back home or cared for. They said, 'We are happy to return but it is others who won't accept us. Even when we are begging, the people drop the money into our hands without touching us!' 'Ulcers don't go, people at home will not look after them.' Many settlers did not want to return home because they were deformed by leprosy. They were cured, but continued to have problems and felt no-one would look after them at home. For some it was the shame of their disabilities. Some of them said, 'I do not want to go home, I am ashamed of my foot which is only half now. Here I can farm, feed, and look after myself.' 'Frequent ulcers prevent me from going home. I cannot do anything because of my hands. I prefer to die here!'

\section{Family and care}

For some people affected by leprosy, the problem was their isolation and lack of family and care at home. 'No family at home, so I have given myself to the Mission-I can't go anywhere!' Others felt their children would be better of $\mathrm{f}$ in the settlement. Some were staying to care for their disabled partners. One said, 'If I go home I cannot look after my children who have no work. Here I farm.' And another, 'My husband has no eyes, he has no legs, I am staying to care for him!' For some, the issue was food. They would not find food to eat, if they went home. Some had tried to return but found rejection or lack of care. For one very old man, 'I have tried to go home but my people do not want me. There is no one to look after me. While I am here, I am cared for.' 


\section{Employment}

Some of the younger and fit looking people stayed in the settlements because there was no chance to get work elsewhere. For a young healthy looking man with an ulcer, 'I have not had help to get a job. God has already helped me with my foot, but I don't have a job.' His father said, 'I was unable to find money to buy tools so that he can start his job.' To buttress this point, one said, 'If I have the health and the money to trade at home, I can go tomorrow!'

\section{Housing}

One group was actually keen to return home but did not have housing. They felt if they could have houses, then they would return home. 'I have wanted to leave here for a long time, but I don't have money to build a house.'

ROLE OF THE LEPROSY HOSPITALS

The majority of settlers wanted health care provision from the leprosy hospitals. Provision and renewal of artificial limbs were also expected. Other broader expectations were farmland, water, electricity and food. 'The hospital should feed us, give us light, water and drugs, ' they said. 'They should provide food for those who are admitted.'

\section{Discussion}

Leprosy settlements in Nigeria are dying communities. This was evident from the age structure of the population of settlers that was observed. It was older than expected for the structure in Nigeria where almost half $(48 \%)$ of the population are children less than 15 years. $^{2,3}$ The population of settlements is apparently declining. There has also been social integration and urbanization of some settlements, where persons affected by leprosy live alongside people not affected by leprosy. This may occur through the process of time. It may also result from the positive influence of the government's 'go-home' policy.

Housing in the settlements appeared similar to the ones in non-leprosy communities in the same socio-economic setting. With the paucity of basic social amenities, leprosy communities are definitely not self-sufficient. The few available amenities are not always within easy reach of the settlers. The daily long walks to streams, shops, mills and farms mean that living in settlements could encourage formation and worsening of disabilities. The settlements at present therefore provide little or no prospect for disability prevention. Driven by self-stigmatization and fear of rejection by the wider society, new settlement admissions of persons affected by leprosy are likely to fall into a vicious rejection-stigma-disability cycle. This cycle may have caused many old settlers to be rejected by their communities and prefer a permanent stay in the settlements despite the apparent difficulties and isolation. Waxler ${ }^{4}$ has noted similar self-stigmatization linked to fear and rejection.

All communities in the region saw their need of care for their multifarious health problems as a prime priority. The other popular expressed needs of these leprosy communities are money and water, where it is a major problem. They also need financial assistance for trading, education of children and housing. The priority need ranked the highest in each community seemed to be a reflection of its particular socio-economic situation. Where the 
communities were more like villages and less dependent on the adjoining leprosy hospital, their needs were more community-oriented, such as health care and water. The more dependent and beggarly communities seem to have money as their overriding need. The sex differences observed in the choice of priorities reflect the traditional roles of men and women in the Nigerian society. Men need better health in order to work on the farms for which they also require fertilizer and assistance. The women, being traders and food providers, need money for their families. The women's concern for school fees shows their care for their children's future although it is unlikely that they were asking for 'leprosy' schools.

The findings of the needs analysis were initially surprising, especially the unexpected emphasis on health care in all settlements. The variety of needs expressed showed clearly the value of this study approach. There is therefore no single solution to rehabilitation in the Nigerian context. Each community needs to be looked at individually, taking into account the particular situation and context. The group in the dormitory-like settlements seemed to be quite hopeless and depressed. For them money was the only way out, particularly if they were old and severely disabled. This indicates that community and social care is important. For such dependent communities, loans for income generation were seen to be a great need. This was also true in a settlement where people were prepared to go home if they could be made independent. The younger and less disabled, given money for trade, would more readily be rehabilitated and reintegrated back to their home communities than the older ones who have resided in the settlements for decades. They are therefore more likely to benefit from a community based rehabilitation programme. Any programme issuing pensions to people affected by leprosy has a poor prospect of sustainability and would continue to create dependency and self-stigma. It will directly provide welfare for settlers, who are old, grossly disabled and cannot help themselves, but it cannot be described as a rehabilitation programme.

The issue of settlers returning home is complex. It seems unlikely that people who have lived in a leprosy community for 20 years or more will be able to resettle in their home villages, particularly if they no longer had family or support there. Some have tried to go back but failed. It was evident that stigma and dependency had played significant roles in preventing settlers from going back home, especially those who wanted to return. For the category of settlers who may never return, an appropriate and sustainable approach to meet their expressed needs should be considered. A policy enabling these long stay settlers to remain in their villages without attracting more people affected by leprosy needs to be developed. The focus of reintegration and rehabilitation could be on young newcomers of less than 5 years, who can still be saved from a disability-prone life in leprosy communities. An active effort should be made to discourage new admissions into the settlements before they enter the vicious disability-stigma-rejection cycle and before close ties with families at home are severed by long absence.

In conclusion, this study shows that we may have to change our approach to rehabilitation and take a more development-based approach, looking at health care provision, water supply and schooling in established leprosy communities. We ought to look at ways to make the more dependent communities less dependent on the founding leprosy institutions. Income generation schemes may also help people resettle at home, and perhaps these can be done through development agencies and be available to whole village groups rather than just people affected by leprosy. It is important that rehabilitation does not further isolate patients by making them different from their peers in the wider society. A fully integrated and holistic 
health service is a dire need for persons affected by leprosy living in settlements. Where this is not possible in general health facilities, it may be met by integrating general services into the existing leprosy hospitals. Mobile consulting clinics from the hospitals to isolated leprosy villages should be considered where no other means of health care provision is feasible.

\section{References}

1 The Leprosy Mission International, Together We Serve, Global Vision and Strategies for the Next Decade. June 1998, Page 1.

${ }^{2}$ Federal Office of Statistics, Lagos Nigeria, Annual Abstract of Statistics. 1996 edition ISSN 00776-0626. p. 45.

${ }^{3}$ Lucas AO, Gilles HM. A New Short Textbook Preventive Medicine for the Tropics. (1991) $3^{\text {rd }}$ edition. Education Low-Priced Books Scheme with Edward Amold, Chapter 2, pp. 5-6.

${ }^{4}$ Waxler N. Learning to be a leper: a case study in social construction of illness. In: Mishler et al., ed. Social Context of Health, Illness and Patient Care, 1981. 